\title{
NEW NON-EVIDENCE FOR THE NAME OF BABRIUS
}

Paris. $g r .2511(P)$, hitherto unnoticed, indicates that the name Valerius Babrius has been wrongly deduced from the evidence of two other $\operatorname{MSS}(A H)$. What we in fact have is two

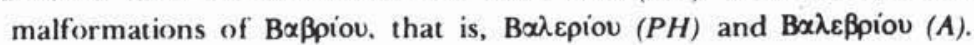

The evidence usually cited for the name of the Mythiambographer includes Harley MS, 3521 ( $=H$, now in the British Museum) '. This MS contains adversaria of Scaliger among those of some seventeenth century humanists ${ }^{2}$. On fol. 17 (recto and verso) an unknown scholar (Dilherr?) has copied Babrius fab. 58 together with the title $B \alpha \lambda \varepsilon \rho i o u ~ \chi \omega-$

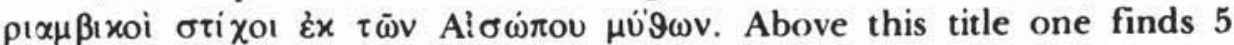
illegible letters followed by $\mathrm{B} \alpha \beta$ piou. It has been suggested that $H$ in effect gives the name Babrius Valerius. Now the principal MS of Babrius, the Athoan codex $(A=B r i t$. Mus. Add. MS 22087), gives the name $B \alpha \lambda \lambda \varepsilon \beta p i o v$, "which may be an error by syncopation for $B \alpha \lambda \varepsilon$ [piou $B \alpha$ Bpioun " ${ }^{3}$. Thus the full name Valerius Babrius may be deduced ${ }^{4}$.

While working in Paris at the Bibliothèque Nationale during the Summer of 1979 , I came across a very close relative of $H$, namely, Paris. gr. $2511(P)$. On fol. 56 recto this MS contains the same fable (58) with the same title, but without the five illegible letters or B $\alpha \beta p i o u$. Again an isolated transcription of fab. $\mathbf{5 8}$, but in a MS some three centuries older than the seventeenth century $H$. Omont dates $\mathrm{P}$ to the fifteenth century ${ }^{5}$, but we may now correct this to the fourteenth. Two watermarks correspond to Briquet nos. 5765-66 and 7497, 7502-3 respectively; these types range from 1348 A. D. to 1383 . The writing too should be dated to the same

\footnotetext{
-The evidence for the name of Babrius is cited and discussed at Crusius, *Babrios". $R E$ II 2 (1896), col. 2656, 47 ss. See also B. E. Perry, Babrius and Phaedrus (Cambridge, Mass. \& London 1965), pp. lii-liii (henceforth: Perry, Babrius); and P. Bádenas de la Peña and J. López. Facal, Fábulas de Esopo, Vida de Esopo, Fábulas de Babrio, Madrid 1978, p. 291.

2 (ff. Clark, CR 5, 1891, p. 365 ss.

${ }^{3}$ Perry, Babrius, p. lii

4 It must be noted that Crusius, Perry and Facal (locc. citt., supra n. 1) all express strong doubts about this deduction.

"Inventaire sommaire des MSS grecs de la Bibliothèque nationale, etc. II, Paris 1888, p. 275 s.
} 
period according to $\mathrm{M}$. Charles Astruc, who very kindly examined $P$ at my request.

Before turning to the new MS we should clear up some difficulties of the old. The main problem here is what we are to make of Bxßpiou and the illegible letters that precede. The following interpretation by Musgrave is supported by autopsy: "In MSto nomini Bxßptov, quod in prima linea clare legitur, praefigitur vocula, ut videtur, Latina, sed characteribus ex festinatione scribentis tam perverse formatis, ut de vera eorum potestate aliquid certi statuere difficillimum sit, nisi forte plura eiusdem manus scripta inspiciendi facultas detur. Coniicere licet, nomen illud $B \alpha \beta p i o v$ esse emendationem alterius, quod infra scribitur, $B \alpha \lambda \varepsilon$ prov.... '.

The four or five letters preceding B $\alpha \beta$ piou certainly seem Roman rather than Greek. Lewis suggests "Versus» - a remote possibility ${ }^{2}$. Less Tikely is Rutherford's view that the copyist set out to write Bxicpiov. stopped at the epsilon, and then erased. $B \alpha \lambda \varepsilon{ }^{3}$. There is no sign of erasure here. Nor does Perry's interpretation convince. According to the latter the copyist first writes $B \propto \beta p i o u$, correcting the erroneous $B \alpha \lambda \varepsilon$ Bpiou of his presumed source, $A$; then "in the second line, on further thought", he substitutes $B \alpha \lambda \varepsilon p i o u$ "in place of his original correction, Baßpiou * 4 .

The evidence of $P$ further confirms Musgrave. The new MS gives the text of fable 58 (closely agreeing with $A H$ ) preceded by the title

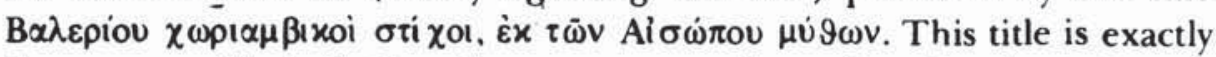
the same as $H$ 's including the error $\chi \omega p-$ for $\chi \omega \lambda$ - . But in $P$ there is no trace of $B \alpha \beta p i o u$ or of the mysterious Latin(?) letters. The obvious deduction is that both $P$ and $H$ go back to a common source best represented by $P$, or $H$ may derive directly or indirectly from $P$ itself. The copyist of $H$ writes the title exactly as it occurs in $P$, and then adds $B \alpha \beta p i o u$ in the line above to correct the erroneous $B \alpha \lambda \varepsilon p i o v$.

Thus $H$ is not evidence for the name B $\alpha \beta p i o u$ B $\alpha \lambda \varepsilon p i o u$, much less Valerius Babrius s. Both $P$ and $H$ give the name B $\alpha \lambda \varepsilon p i o u$, a malfor-

\footnotetext{
'Musgrave apud Tyrwhitt, Diss. de Babrio (London 1776), reprinted at Fabulae Aesopicae ed. F. de Furia (Leipzig 1810), pp. CLIII-CCIII. Musgrave is cited at Furia p. C(CIII. Note that the Leipzig ed. of Furia reprints the original ed., Florence 1809, and very usefully includes inter alia Bentley on Aesop and Tyrwhitt on Babrius.

${ }^{2}$ "On the Fables of Babrius", Philological Museum 1, 1832, p. 292 n. on fab. 4, 7.

${ }^{3}$ Babrius ed. W. G. Rutherford, London 1883, p. xix.

4 Perry, Babrius, p. liii n. 1.

s....Babrius Valerius... is by no means equivalent to Val. B., which alone is plausible as a Roman name.* Perry, Babrius, p. liii.
} 
mation parallel to $A$ 's $B \alpha \lambda \varepsilon \beta$ piou, itself possibly the ancestor of $P H$ 's misnomer '. As for "Valerius", requiescat in pace, or at least apud L. Herrmann ${ }^{2}$.

JOHN VAIO

' Cf. Perry, Babrius, pp. lii-liii.

${ }^{2}$ Babrius et ses poèmes, Brussels 1973, p. 22. 